\title{
Use of systemic antifungal drugs in critically ill patients. data from the envin-helics registry 2013-2014
}

\author{
N Mas ${ }^{1 *}$, P Olaechea ${ }^{1}$, M Palomar ${ }^{2}$, F Álvarez-Lermo ${ }^{3}$, S Otero ${ }^{4}$, S Uriona ${ }^{4}$, M Catalán ${ }^{5}$, ENVIN-HELICS Group \\ From ESICM LIVES 2015 \\ Berlin, Germany. 3-7 October 2015
}

\section{Introduction}

Flora in ICUs has changed with the development of new therapies and the implementation of protocols regarding bacterial infections. As a result, this could increase our concerns about fungal infections and modify the indications and the way we use them.

\section{Objectives}

To assess the indications for the use of antifungal drugs (AD) during the 2013-2014 period using data from the ENVIN-HELICS registry.

\section{Methods}

Data regarding the use of $\mathrm{AD}$ in patients admitted to ICU for over 24 hours is gathered. Different kinds of amphotericin are grouped (deoxycholate, liposomal and lipid) (AMP), as well as echinocandins (caspofungin, micafungin and anidulafungin) (ECH). Fluconazole (FLU) and voriconazole (VOR) are considered as different groups. Data from the 3 months of each year when the registry is complete is used. The indications are divided in prophylaxis, treatment of community-acquired infections, treatment of in-hospital acquired infection (out of ICU) and in-ICU acquired infection treatment. Whether the $\mathrm{AD}$ is started as a specific therapy or empirically is also studied; in the latter the microbiological results (positive or negative), the adequacy, modifications of $\mathrm{AD}, \mathrm{AD}$ combination and sequential therapies are analyzed. Results are shown as percentages of the used AD.

\section{Results}

2417 patients were treated with AD. 400 received more than one $\mathrm{AD}$ and 72 of them more than 2. Overall in-ICU

${ }^{1}$ Hospital Galdakao-Usansolo, Intensive Care Unit, Galdakao, Spain Full list of author information is available at the end of the article mortality was $36.4 \%$. Length of stay average was 18.7 ( \pm 19.3 ) days. First choice of AD is shown in the table.

Of 1481 cases where the $\mathrm{AD}$ is started empirically, the adequacy is confirmed in $21.3 \%$; in $45.0 \%$ of the cases the cultures were negative or were not collected; in $15.8 \%$ the infection is not confirmed. Mortality of those patients treated with more than one AD was $60.0 \%$. In 62 cases $(2.5 \%)$ both agents were initiated at the same time, but only in 25 of them the combination was used for more than 48 hours. The most frequently used combination was VOR plus caspofungin (32.0\%). 260 patients $(10.7 \%)$ received sequential therapy; these changes were justified as adjustment of the spectrum $(33.2 \%)$, worsening of the clinical status (31.6\%), toxicity (8.6\%), development of resistance during the $\mathrm{AD}$ use $(0.5 \%)$ and other reasons (12.3\%). Among the 59 cases were the $\mathrm{AD}$ was switched due to a worsening of the clinical status, 51 were initially treated with FLU (86.4\%) and switched to ECH in 45 cases (76.2\%). Mortality in ICU in the latter group was $59.3 \%$.

\section{Conclusions}

AD use in critically ill patients is described. FLU was the most frequently used AD. Microbiological confirmation was scarce. Combined AD therapy was rarely used, while sequential $\mathrm{AD}$ were more frequently administered (10.7\%). The switch to FLU was seen in order to reduce the spectrum of the therapy, whereas $\mathrm{ECH}$ were the choice when the clinical status worsened; mortality in the latter group was high.

\section{Authors' details}

${ }^{1}$ Hospital Galdakao-Usansolo, Intensive Care Unit, Galdakao, Spain. ${ }^{2}$ Hospital Arnau de Villanova, Intensive Care Unit, Lleida, Spain. ${ }^{3}$ Hospital del Mar, Intensive Care Unit, Barcelona, Spain. ${ }^{4}$ Hospital Vall d'Hebron, Department of 
Table 1. First choice of AD according to indication

\begin{tabular}{|c|c|c|c|c|c|c|}
\hline & $\begin{array}{l}\text { Total }(\mathbf{n}), \\
(\%)\end{array}$ & $\begin{array}{l}\text { Empirical } \\
(\%)\end{array}$ & $\begin{array}{c}\text { Prophylaxis } \\
(\%)\end{array}$ & $\begin{array}{c}\text { Community-acquired } \\
\text { infection (\%) }\end{array}$ & $\begin{array}{l}\text { Out of ICU acquired } \\
\text { infection (\%) }\end{array}$ & $\begin{array}{l}\text { In-ICU acquired } \\
\text { infection (\%) }\end{array}$ \\
\hline Fluconazole & 1296, (53.6) & 48.5 & 63.5 & 48 & 47 & 61 \\
\hline Echinocandins & 807, (33.4) & 39.2 & 25.9 & 32.8 & 37.7 & 31.7 \\
\hline Amphotericin & $89,(3.7)$ & 3.3 & 3.4 & 5.9 & 3.9 & 2 \\
\hline Voriconazole & $225,(9.3)$ & 8.9 & 7.1 & 13.2 & 11.3 & 5.1 \\
\hline Total (n), (\%) & $\begin{array}{l}2417 \\
(100.0)\end{array}$ & $1481,(61.3)$ & $351,(14.5)$ & $454,(18.8)$ & $926,(38.3)$ & 686,(28.4) \\
\hline
\end{tabular}

Preventive Medicine, Barcelona, Spain. ${ }^{5}$ Hospital 12 de Octubre, Intensive Care Unit, Madrid, Spain.

Published: 1 October 2015

doi:10.1186/2197-425X-3-S1-A398

Cite this article as: Mas et al.: Use of systemic antifungal drugs in critically ill patients. data from the envin-helics registry 2013-2014.

Intensive Care Medicine Experimental 2015 3(Suppl 1):A398.

Submit your manuscript to a SpringerOpen ${ }^{\mathcal{O}}$ journal and benefit from:

- Convenient online submission

- Rigorous peer review

- Immediate publication on acceptance

- Open access: articles freely available online

- High visibility within the field

- Retaining the copyright to your article

Submit your next manuscript at $>$ springeropen.com 